\title{
Growth Patterns
}

\section{Emily Tatti}

The EARLY-MORNING sunLight casts a spotlight on Claire's face. It allows me to observe her without her knowledge and I savour the rare luxury. I know she would hate it. She's so self-conscious she has trouble making eye contact with people sometimes; even me.

She's still so young. The yellow light illuminates the down on her cheeks, and the skin beneath is smooth and blemish free, like something on the cover of a magazine. She's nearly a third my age, not that she will ever know that. To her, I look like I'm in my early thirties, but I was eighty-one last September.

I was due for my most recent HAADT treatment yesterday. I know the date by heart, despite the fact that the appointment is only necessary every twenty years. But since I met her I find it easy to pretend that disco was a dumb fad my parents went through, and that the Sydney Opera House has always been there, and that I love Bob Dylan and Pink Floyd because I have good taste in music, not because I can't understand the point in anything that came after them.

It was a rude shock this morning when I went into the bathroom to shave and I saw the silver strands multiplying in my hair, like a spider threading its web on my scalp.

I have never been a day late before.

'The line gets longer every time.'

The man behind me jars me out of my recollections, and though he isn't wrong, I don't look at him or acknowledge his complaint. I don't want to be drawn into a conversation, not here.

'Which visit is this for you?' he asks.

For God's sake. 'My third,' I say.

'You mean to tell me I actually found someone with a bit of experience under his belt? I doubt you could find two other people 
in this room who remember the good old days - back when they had some standards about who they let in here. All these bloody socialites think they're at a day spa.'

I'm forced to follow his gaze so I can take in the people around me. Most of them have the look of patients waiting to see the doctor about something embarrassing. Their physical flaws - the wrinkles, the chin fat, the sallow eye sockets - are all enhanced under the florescent lights, though they've done their best to conceal them with cosmetics and plastic surgery. As they've no doubt discovered, there are only so many times you can tug and prod at your skin before it wears like leather. I feel sorry for them, but in a detached kind of way, because it will be a few decades before they truly understand the decision they're making, and by then it will be too late.

What would Claire think if she were here? This is the first time I've really had to consider the idea. We've only been together for three years. She's not a judgmental person, but I suspect she would be quietly appalled. I specifically remember in her online dating profile, she wrote: 'I'm not one of those girls who likes to spend a lot of time in front of the mirror.' I have more skincare products in our bathroom than she does. She would not understand the way they - the way we cling to our youth like this.

I rest my hands awkwardly against my sides and try to appear relaxed, but I don't think I will be reassured until I can get to the front of the line. Even forgetting minor appointments makes me uneasy this is something else entirely.

Claire will be at work now. She thinks I have a doctor's appointment, which I suppose is partly true. I can picture her sitting behind her desk with her glasses on the edge of her nose. She'll be so engrossed in her blog she won't even notice she's pressed up against the computer screen. It's only later, when we're at home, that she'll complain she has a sore neck and I'll have to give her a back rub to fix it. She'll squirm and sigh under my hands before gradually giving in, and that's when she'1 start opening up about all the silly little problems she had that day. She speaks so sparingly that every word she utters is like poetry to me. 
Just thinking about her fills my insides with warmth, and I stop feeling quite so agitated. In a few hours, we'll be back there and everything will be fine. I just have to get through this first.

'Next,' the woman at the counter calls, and the man behind me exhales.

'Finally.'

I silently agree with him, but then he slaps me on the back, and I hate him for being so familiar. Why are people like that with you in queues? It's not as if you've been through the trenches together.

The woman behind the glass is impossibly youthful. She examines my grey hairs with disinterest. She no doubt assumes this is my first time here. 'Name?'

'Will Stevenson.'

Her manicured nails hover over the keyboard, and I want to wrench it away from her and do the typing myself, but I hold still and wait for her to finish. When she retrieves the right record, her features crease. 'You were due to meet with us yesterday morning, Mr Stevenson.'

'Yes I know. I have to admit I . . f forgot.'

She looks oddly troubled, but I'm sure this sort of thing happens all the time. I can't be the only absentminded patient they have on the books.

'Excuse me for a moment; I just have to check something with the doctor.'

She ambles through a back door and leaves me standing at the window, which is rather unprecedented. I fidget and look selfconsciously behind me. The man in line lifts his eyebrows as if to say, 'What's the hold up?'

When the woman returns, the doctor is with her, and he looks out of place behind the glass. He usually greets me with a clipboard in a chair.

'Has no one ever explained the procedure to you, son?' he asks softly, like a bank teller disclosing your bank balance. 'The rules about the regimen?'

What the hell is he talking about? I barely remember anything about that first time; it was so long ago now. 
'Your treatments hinge on very regular injections,' he explains. 'An out of cycle treatment can have adverse side-effects. This would have been in the contract you signed.'

I can briefly glimpse the contract in my memory, but I'm not entirely sure I read all of it.

'So what would be our next move then?'

'I'm afraid as you've broken the terms of the contract, there is no next move. Once age-defying therapy is stopped, the HAADT drug is resistant. There is nothing I can do for you.'

A security guard lingers in the periphery of my vision, as if he expects me to make some kind of scene. I'm still not entirely sure I understand what is happening here.

'Sir?' the doctor asks, but he sounds so far away. 'It would be in your best interests to seek outside medical treatment immediately. You're already twenty-three hours overdue. The reversal process can happen quite quickly.'

The reversal process can happen quite quickly. I can see myself in the glass. I look fine, aside from the grey hairs. Just the same. For another second I stand there with my hands curled into fists, and I can tell the nurse and the doctor and the security guard are all wondering what I'm about to do because they're staring at me like they're poised for an attack. The man behind me also stares with undisguised fascination. I need to get out of here.

I turn away from the window and rush back out the way I came in, the way nobody goes.

From the outside, the whitewashed office looks unremarkable. If you didn't know what was inside, you would never suspect it. I stumble from the curb and across the street to join the crowd of oblivious passers-by.

A tram trundles by and I let it pass I catch my reflection in its windows and I still look fine. Fine, fine, fine. I sag against the stop post and draw in a deep breath. He's wrong he has to be. 
But then I look down at my hands and they are translucent; the veins protrude and rearrange themselves like baby snakes writhing under the surface of my skin. Previously unblemished, they are now speckled with liver spots. For a surreal moment, I'm reminded of a documentary I once saw about tree-ring dating. The presenter crouched by a felled trunk and ran his hands over the growth patterns. He explained that one ring marks the passage of one year in the life of the tree. If I count the number of lines on my hands now, will I be able to determine my real age?

'Are you all right?' a woman asks, touching me on the arm.

I look up at her, but there are cataracts obscuring my vision. I see only an indistinct halo of brown hair. Nonetheless I'm certain I know her. It's Claire; it has to be. And she doesn't know me. She doesn't love me. To her, I am just an old man on the street. 